\title{
Modernism in the Poetry of Abdul Wahab Al-Bayati and T. S. Eliot: a Comparative Study \\ Dr. Thabit Shihab Ahmed Ahmed
}

\begin{abstract}
This study deals with modernism through the use of symbolism and myth in addition to crisis topic in the poetry of the great Iraqi poet Abdul Wahab Al-Bayati and the American English poet T.S. Eliot. The impact of Western literature on the new generation of Arab poets and writers can be traced. The global concerns of postcolonial Arab poets who have been exposed to the influence of Western modernity indicate the gradual disappearance of literary history paradigms that isolate poets by race, language, gender, or geography. With the exception of prominent poets who have a strong foundation and trust in their authentic Arab heritage, the most prominent of these poets is Abdul Al-Wahab Al-Bayati.He is the mastermind of many legends and the creator of the mask in contemporary Arabic poetry.T.S. Eliot preserved a great deal of reverence for Western myths and literary traditions, and he filled his work full of hints, quotes, footnotes, and scientific interpretations. Eliot praises literary traditions and states that the best writers are those who write with a sense of continuity with these writers who have come before, as if all literature is a series of forms that every new writer must introduce.Eliot creates a personality that exemplifies perfection, represented by one body for both genders.
\end{abstract}

Key words: Modernism, Symbolism, Mythology, Al Bayati, Eliot. 
الحداثة في شعر عبد الوهاب البياتي و ت. س. إليوت: دراسة هقارنة

\section{د. ثابت شهاب احمد احمد}

نبذة مختصرة: - 2 - 2

تتناول هذه الدراسة الحداثة من خلال استخدام الرمزية والأسطورة بالإضافة إلى موضوع الأزمة في شعر الثاعر العراقي الكبير عبد الوهاب البياتي والثاعر الأمريكي الإنجليزي T.S. إليوت. يمكن تتبع أثر الأدب الغربي على الجيل الجديد من الشعراء والكتاب العرب. تشير الاهتمامات العالمية للثعراء العرب بعد الاستعمار الذين تعرضوا لتأثير الحداثة الغربية إلى الاختفاء التدريجي لنماذج التاريخ الأدبي التي تعزل الثعراء عن طريق العرق أو اللغة أو الجنس أو الجغرافيا. باستثناء الثعراء البارزين الذين لايهم أساس قوي وثقة في تراثهم العربي الأصيل، كان أبرز هؤلاء الثعراء عبد الوهاب البياتي. إنه العقل المدبر للعديد من الأساطير ومبدع القناع في الثعر العربي المعاصر • حافظ تى اس إليوت على قدر كبير من التبجيل للأساطير الغربية والتقاليد الأدبية ، وقد ملأ عمله بالتلميحات والاقتباسات والحواشي والتفسيرات العلمية. يشيد إليوت بالتقاليد الأدبية ويذكر أن أفضل الكتاب هم أولئك الذين يكتبون بشعور من الاستمرارية مع هؤلاء الكتاب الذين أتوا من قبل كما لو أن كل الأدب عبارة عن سلسلة من الأشكال التي يجب على كل كاتب جديد تقديمها. إليوت يخلق شخصية تجسد الكمال، ممثلة بجسم واحد لكلا الجنسين.

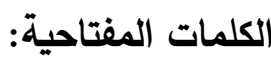
الحداثة، الرمزية، الأساطير، البياتي، إليوت. 
Modernism in the Poetry of Abdul Wahab Al-Bayati and T. S. Eliot: a

Comparative Study

Dr. Thabit Shihab Ahmed Ahmed

مجلة وادي النيل للاراسات و البحوث الإنسانية والاجتماعية والتربوية (مجلة علمية محكمة)

\section{Introduction}

The term "modern Arabic poetry" refers to poetic poems that were organized in modern times. This includes a first poem written before the French campaign against Egypt at the beginning of the nineteenth century, until the last poem written today. Modern Arabic poetry does not follow old poetry in terms of style, content, characteristics, and themes.

.Modern Arabic poetry was moving in a long and winding way before reaching the new, flexible and easy shape known as free poetry. Before Arab poets realize that poetic experience paints its own form, poetry draws its own scales and rhymes that experience is not of great importance. The revolution or transformation against the refined, consistent and harsh poem in Arabic literature began with the first real contact between Arabs and Western poetry. Through attempts to translate European poetry into Arabic and imitating its contents and forms, which led to the imitation of Western rhymes and the adoption of similar methods at the level of classical Arabic poetry as well as popular poetry (Moreh, 1976: ix).

The researcher in Arabic literature must search in Iraqi literature. Modern Iraqi poetry is distinguished by its quality and the presence of beautiful creative details. Political events and transformations that have taken place in Iraq have contributed to the adoption by poets of a trend that distinguishes them from other poets of the Arab world. In addition, the communication with Western countries through missions and migrations abroad contributed to the development of Iraqi poetry and change in the trend in the country before that communication and before these migrations.

The discussion of the term free poetry has taken much of the effort of critics and poets and wasted their energies in a long debate. However, what is important here is that many Arab poets and critics have been referring to the peculiarity of modern Iraqi poetry. Nevertheless, their references are not free to mention negative remarks, such as exaggeration in the themes of grief, pain, war and death, and repeated vocabulary that overwhelms certain 
topics and coloring the Iraqi poetry scene. There is even a description of Iraqi poetry with violence, for the violence of its poetic image.

The Iraqi poet cannot completely get out of his community. There are interactions, influences and dominance, and this is evident in the style of the Iraqi poem and its artistic and stylistic treatments and subjects, which characterized by other methods in the writing of Arabic poetry. Despite the political circumstances of Iraq for almost half a century, forcing hundreds of Iraqi poets to leave Iraq and live in countries completely different in their cultures and nature. Usually precedes access to these countries trip different stations; these countries such as Jordan, Syria, Turkey, Greece, Pakistan, Malaysia, Indonesia, Italy, France, Britain, Spain and others. This gave the experience of poetic Iraq in general and especially the experience of poetry free poetry the linguistic richness and variety of experiences, methods and subjects. Not denying the strength of foreign and especially Western experiences represented by the experiences of poetry of English, French, American, Spanish, Russian and other experiences to varying degrees.

In most Middle Eastern countries, poetry is celebrated with the highest respect. In Iraq, mosques, religious schools and traditional institutions were naturally associated with the state and were incubators and protectors of traditional poetry. Formal poetic form is specialization in cities. Poetry was very important in Islamic times, where poets worked as historians and preachers. The first poems were collected in the 18th century. They were referred to as hanging poems, hanging in the holiest place in Islam, in the Kaaba in Mecca. Arab poetry was influenced by the Persian civilization as we saw in romantic and heroic stories, and poems with Sufi themes. While traditional distinctive poetry and scripture to create a state of ecstasy characterize Sufism in Islam. At the turn of the twentieth century, Iraqi poetry followed the traditional form and linked itself to poems for official occasions such as weddings, poems praising the Prophet and high-level religious and tribal figures. 
In general, literature is a fine expression of feelings, ideas, opinions and human experience. Iraq is considered the best ambassador in this field through writers and poets who belong to Iraq through different times. The Iraqi literature cannot be influenced only by the Arab arena, but it was a pioneer of modern and old Arabic literature alike. The Iraqi literature may have suffered a setback reflected by the political setbacks and crises experienced by Iraq. Nevertheless, at the same time, it can be said that politics has a role in stimulating the pens on writing. The trend of rebellion in the poetry of the great Abdul Wahab Al-Bayati, who formed with a group of his contemporary poets the leading role in modern Iraqi poetry. They were able to make the poetry away from monotony and stereotyping and repetition.According to Dina Rizk Khoury, the First World War was characterized by the emergence of new literary topics in the poetry of Iraqis and their literary stories. Much of the poetry written during World War I touched upon the virtues of nationalism and Islam (Khoury, 2010: 333).

The poet Abdul Wahab Al-Bayati is one of the most famous poets and writers who carried the obsession with leading modern Arabic poetry in Iraq. He is the mastermind of many legends and the creator of the mask in contemporary Arabic poetry. The sources of heritage of Al-Bayati's works were varied, literary, historical, religious, traditional, popular and legendary. Therefore, he was evoking models and personalities of many and different in terms of sex and race. Al-Bayati has dealt with the themes of revolution, oppression, extortion, exile, alienation, rebellion, pain, suffering, and death. In fact, Al-Bayati was the fruit of the glorious past that represented for him the highness, culture and glory. His faith in the unity of human experience is very great. He has always been trying to break the limited and narrow-minded concepts and rebel against the stillness of the world and life in order to achieve freedom, justice and human dignity.

The Iraqi poet, Abdul Wahab al-Bayati, has a high position among the Arab poets of the twentieth century. He has a unique experience characterized by style and richness of ideas and themes. 
As well as the emergence of the firmness of the affiliation and methodology of its founding root in his field, which represents the entire life, which is the arena of poetic creativity.Abdul Wahab alBayati is considered the leader of the social-realist movement in modern Arabic poetry. He was committed to the radical transformation of developing societies, including Arab states. Al Bayati gave up the romantic tradition of Arabic poetry, with themes that include reclaiming memories from childhood, love and suffering, and turned his writings on real themes: poverty, Palestinian refugees, and the working class everywhere in this world.The poet Abdul Wahab al-Bayati lived in Spain during the period between 1970 and 1980, and this period can be called the Spanish stage in his poetry, where he became like a prominent Spanish writers. As he became known at the level of official and popular wide. In addition, a collection of his poems and poetic works translated into Spanish. For him, poetry is the link with the West and the easy and correct way for the West to understand the culture of the East.

Abdul Wahab al-Bayati's poetry is characterized by his tendency towards contemporary universalism influenced by his life and experiences, which have been shaped by his living in several countries of the East and West. In addition, his extensive relations with the world's great writers and poets, such as Turkish poet Nazem Hikmet, Spanish poet Rafael Alberti and Russian poet Yevtushenko. The poetry of Abdul Wahab al-Bayati is also characterized by its confusion with the heritage and mystical and mythological symbols, which formed one of the most important features in his poetic presence and modernism.

The history of the track of Al- Bayati's poetry began with the issues of the countryside, the city, the workers, the poor and the exile, as in its collections"Mala'ika wa Shayateen" (Angels and Devils) in 1950, "Abareeq Muhashama" (Smashed Pitchers), 1956, "Ash'ar fi al-manfa" (Poetry in Exile), 1957, "Kalimat La Tamout" (Undying Words), 1960, "Kitab al-bahr" (Book of the Sea), 1975 and "Al Mawt fi al Hayat"1968. It was the beginning of what critics call the realism of monetary life of Arab and then moved to 
Modernism in the Poetry of Abdul Wahab Al-Bayati and T. S. Eliot: a

Comparative Study

Dr. Thabit Shihab Ahmed Ahmed

مجلة وادي النيل للار اسات و البحوث الإنسانية والاجتماعية والتربوية (مجلة علمية محكمة)

the stage of research and suspicion of its religious and mythological dimensions.According to Thomas Levi Thompson, there is no dispute that the literary sphere of Al- Bayati covers a wide range of cultural and linguistic traditions through his long poetic career. However, for Al-Bayati, the main source of poetic inspiration is Arabic literature in all its fields. The poet Al-Bayati is constantly returning to his own tradition to inspire his poems with echo from the depth of Arab history spanning thousands of years (Thompson, 2017: 218).

Abdul Wahab Al-Bayati believed in the history as a main subject and believed that it was not only the Arabs who made the eternal Arab civilization in Al-Andalus but also all the different nationalities who belonged to different countries and to different religions. For the first time, history was based on genuine human civilization cooperation, accomplished by scholars, intellectuals and poets from the East and the West alone, away from the politics that were preoccupied with its violence at the time. For example, universities in Granada, Cordoba and Seville have been a meeting place and a cultural center for scientists from all over the world.

In general, in the literary world there were many famous writers and poets who believed in East-West communion and believed in modernism, in addition to their belief in magic, mystery and mythology. Perhaps the most famous of them was the great poet $\mathrm{T}$. S. Eliot,a Nobel laureate in literature in 1948. Thomas Stearns Eliot considered one of the twentieth century's major poets; Eliot attracted universal attention for his poem "The Love Song of $\mathbf{J}$. Alfred Prufrock" (1915), which was seen as a model of the Modernist movement. This poem was followed by some of the famous poems in the English literature, including "The Waste Land" (1922), "The Hollow Men" (1925), "Ash Wednesday" (1930), and Four Quartets (1943).

Eliot was bornon September 26, 1888in the USA and moved to Britain, then became a British citizen in 1927 . He was a modern poet in addition to being different and distinct from the Romantic poets and Victorians of the nineteenth century. Both the verse and 
prose of Eliot created a true revolution in the fine taste of his generation. His first poems bore the characteristics of humor and irony in addition to being so dramatic and impersonal with disrespect for the socalled benefits of civilization. Eliot had been influenced by Elizabethan and Jacobean writers, and he had studied and chosen as guides Dante Alighieri and John Donne. One of Eliot's most important works was "The Waste Land" - one of the great poetic works of modern times. The poem represents the failure of modern civilization through the scenes of ruin and social vacuum. Indeed, Eliot had a great influence on his generation by creating a new poetry revolution.

Eliot was unquestionably the leading voice of modern English poetry. He was famous and contemporary poet with certain commonalities. He was fully aware of the place of man in history and of the spirit in eternity and saw history as a picture of the spirit. In addition, whether inspired by the Russian Revolution or the violence and terror of World War I, he portrayed a moderate Europe which was literally collapsing, devoid of a sense of rationality that fed both Europe and America beyond enlightenment.

Eliot was a famous literary critic and poet. From 1916 to 1921, he contributed about a hundred articles in various international magazines.His critical intelligence and remarkable training in philosophy, literature, and essays, however hastily written and for any motive produced an immediate effect. His ideas soon developed into a doctrine and became the basis for new criticism, and are one of the most influential schools of literary study in the twentieth century.

Eliot is an important character in the twentieth century drama. From the beginning of his literary career he was leaning toward drama. His early poems were mainly dramatic and theatrical, and many of his articles and early reviews were on the drama.His aim, which was only partially achieved, was to stimulate poetic drama in a manner consistent with modern times. He has tried language, although close to contemporary discourse, but it is fundamentally poetic, and thus it is capable of spiritual, emotional, and 
Modernism in the Poetry of Abdul Wahab Al-Bayati and T. S. Eliot: a

Comparative Study

Dr. Thabit Shihab Ahmed Ahmed

مجلة وادي النيل للاراسات والبحوث الإنسانية والاجتماعية والتربوية (مجلة علمية محكمة)

intellectual resonance. His works influenced many important playwrights of the twentieth century, including W.H. Auden and Harold Pinter. Eliot also offered outstanding contributions as an editor and publisher.

\section{The visions of Eliot and Yeats on Modernism}

In the birth of modernism, many critics offer a radical revision of our understanding of modernism, and the realization that modern and postmodern and theoretical criticism inspired a new study of high culture in the first half of this century. Some reject modernism as positive and influential, despite statements made in the 1920s by modernists such as Pound, Eliot and Joyce. They also reject the new critical view of modernity that is completely contradictory, such as pessimism and proportionality. The use of myth in modern literature is a deceptively familiar subject: Joyce's appropriation of Homer's Odyssey and T.S. Eliot's of Frazer's Golden Bough, like Lawrence's primitivism or Yeats's nationalist folklore, show the metaphysical underlying a more fragmented world. In literature, we talk about modernity and myth, and some critics study the relationship of myth and modernity to postmodernism. Legend shows that they are inherently flexible. It was adopted to justify Pound's overall vision of society, which eventually descended into fascism, and the liberal and cynical vision of human existence that explained by Joyce and Mann. These theories, which present myth as another form of mystery, seek the wrong origins, ignoring their use by the modernists to emphasize the ultimate ambition of all values. This contrasting element, as critics argue, can make the myth of behaviour a correction of ideological criticism. Critics show how the postmodern concerns of political and social responsibility, and the role played by literature in shaping this, have in fact come down from modernity.

For Abdul Wahab Al-Bayati, the concept of modernism affects both form and content, and is not only related to the superficiality of things, it is not limited to a time without time or environment 
without another, and each time has modernism and imitators, moreover each poet has distinct visions And his own position in life and society.Al-Bayati's poetic experience represents a qualitative addition to the comprehensive Arab poetic experience in its structural and semantic development, and in the field of modernizing the nature of Arab poetic discourse, had it not been for the leadership of Al-Bayati's poetry, and its renewal with his colleagues of the poetic movement in Iraq, the contemporary poetic movement would not have existed, and it could To say that AlBayati's experience in poetic works played an important role in influencing and distinguishing in the modernist structure.

To conduct a comparative study on Eliot and Al Bayati, we can write that one of the comparisons between the two poets is their common view on the function of poetry, especially the importance of linking artistic innovations and the nature of the social and political conditions of the times. Eliot's poetry changed the form, technique and contents of Arabic poetry to an extent unprecedented in the history of Arabic poetry entirely (Moreh,1976: 216). This included the use of symbol and legend. Such an approach would save the poet from the direct statement and add freshness to his poetry. Thus, contemporary Arab poets adapted Eliot's provocative methods to express their problems and those of the Arab world: poverty, illiteracy, disease and exploitation.

To better understand these two poets, it is necessary to review some of the facts and backgrounds that influenced them, as well as to include similar historical elements in their poems. In fact, their poetry dealt with several topics, including age, time, humanity, love, psychology, apocalyptic, and crises. These themes, which have advanced themselves in the poems of Al-Bayati and Eliot, are already considered universal and influential on each reader and follower of these two well-known poets. Al-Bayati and Eliot took advantage of the aspects of life that are related to the essence of humanity. Through the writings of these poets and through the subjects they addressed, one can begin with a clear knowledge of himself, and of the humanitarian situation in general. Al-Bayati and Eliot wrote poetry that clearly identified the needs and desires 
Modernism in the Poetry of Abdul Wahab Al-Bayati and T. S. Eliot: a

Comparative Study

Dr. Thabit Shihab Ahmed Ahmed

مجلة وادي النيل للار اسات و البحوث الإنسانية والاجتماعية والتربوية (مجلة علمية محكمة)

of their time. They wrote about the social and political chaos, confusion in human life, and the urgent need for order; but the reasons assumed by them were not different in the world's problems, making it clear that they had described different issues with completely different consequences, and among the most important of these topics:

\section{1. Theme of crisis}

Al-Bayati and Eliot proved the crisis of modern society in their poetry. Both poets were concerned about the bad social situation and the disintegrating society of their time - at the time of political turmoil and social chaos. The nostalgia had taken them to the past that was full of humanity, culture, and sophistication, while their chaotic contemporary world deprives people of peace, happiness, and well-being. Their poetry presents an exhibition of characters who had presented their intellectual conflicts, cultural differences, and racial discrimination with a real crisis in the modern society. Both poets expressed dissatisfaction with the disintegration of the modern society which in the past had strong traditions, customs, and values, and people who enjoyed happiness, well-being, and peace. For them, the absence of moral and religious values leads to the constant political, social and economic distress, anxiety, and chaos. However, although both Al-Bayati and Eliot dealt with the issue of crisis, the implications of its treatment are remarkably diverse. The theme of crisis is also a division in the society that highlights them in their poetry by achieving the discrepancy between some common binaries.By trying to define the modern characteristics of Al-Bayati's poetry, we find that their features do not differ from the totality of contemporary Arabic poetry; still, his poems give us deep insights into the development of the free verse. In fact, his poetry was involved in promoting the modernization of Arabic poetic discourse.

In 1965, Al-Bayati published his ninth set of poetry, Sifr al faqer wa al Thawra (The Book of Poverty and Revolution), to open a new style and reach a new peak in his poetry career. For 
several years before that, he had been searching for a new structure that embodied his vision and seemed to be in the midst of a literary crisis. In the past fifteen years, he firmly established himself as a prominent Arab poet in the Free Verse Movement, with a politically committed leftist stance to support the cause of the poor, the marginalized, the workers and the afflicted masses in the Arab world and elsewhere, to criticize the oppressors and their flatterers, and to call for radical change (Boullata, 2001: 107). Despite his praise for his literary accomplishments and political commitment, he was looking for a new way to continue his engagement in the fight against injustice, but he did not want it to be a repeated or to appear as intellectual or dogmatic voice.

The modernism of Al-Bayati placed his poetic region in the seed of a similar dream, with the hallmark of the smallest transmission of poetry revealing a summary of the topics. It is a poetic style that deals with sound and phenomenon and forms the phrase as it understands it through logical research, and it is the method proposed by Al-Bayati to achieve the highest goals of the model in the Platonic symmetry and integration and creative contemplation with the characteristics of modern poetry and careful observation through the reality that represents the phrase, and to stop feeling the rhythm because it interferes with levels of conscious feeling. Al-Bayati was the person who attracted things to relative infinity in search of the beginning in the process of thinking through the problematic of meaning in the new from analysis and observation in vision and poetic approach towards knowledge of modernism.His poem "The City" clearly explains these topics:

"When the city understand herself

I saw in her sad eyes:

The shabbiness of the leaders, thieves, and pawns.

I saw in her eyes:

The gallows, the prisons, and the incinerators,

The sadness, the confusion and the smoke.

I saw in her eyes:

All men 
Modernism in the Poetry of Abdul Wahab Al-Bayati and T. S. Eliot: a

Comparative Study

Dr. Thabit Shihab Ahmed Ahmed

مجلة وادي النيل للار اسات والبحوث الإنسانية والاجتماعية والتربوية (مجلة علمية محكمة)

Glued like postage stamps

On everything."(Al-Bayati, 2004: 17)

T.S. Eliot, the most influential poet of the modern era according to many critics, seeks to express the weakness of the psychological state of human beings in the twentieth century. Modernist writers like Yeats aimed to grip the world, which they see as broken, alien, and humiliating. Eliot also saw the society as lost and sterile and imagined that culture, which is the solution to all the problems of the difficult reality, has faded and deteriorated. In hispoems, especially in "The Waste Land", he automatically mixed myths with current situations to show the loss of the modern world. In the case of Eliot, myths began to gather and coalesce years before his death, which in nature is enough to remember that he lived the life of a well-established poet for more than four decades.

Eliot believed that culture was divided between the high culture of the hand and the low culture of the other. He believed that high culture, including art, opera, and drama, was declining and deteriorating, while popular culture was, from his point of view, expanding. In "The Waste Land", Eliot combined high culture with low culture and proved that people from both kinds are sexually discouraged or not operating normally or properly, and are unable to deal or communicate with one other. According to George Williamson, Eliot's contrast between life and death showed that people of "land waste", losing their spiritual values and morals, are fascinated with death instead of life. Death is the last goal of the land of waste for the people whose interpretation is just a myth, whose sex is devastating rather than creative, and whose will of faith is frustrated by the fear of life (Williamson 1998: 129).

The death and birth in Eliot's poetry were closely linked to each other: water represents death, which contradicts the common concept of water as a symbol of revival or life. In the depiction of modern society, everything from this material world, including water leads to death. They have corrupted the symbol of life, which 
مجلة وادي النيل للاراسات والبحوث الإنسانية والاجتماعية والتربوية (مجلة علمية محكمة)

(ISSN : 2536 - 9555)

is water, and have made it into something that is feared rather than worth it.

"Here is the man with three staves, and here the Wheel, And here is the one-eyed merchant, and this card,

Which is blank, is something he carries on his back,

Which I am forbidden to see. I do not find

The Hanged Man. Fear death by water." (Eliot, Ricks, \& McCue, 2015: 53)

In fact, "The Waste Land" is primarily a poem that embodies a chaotic life that has spread among individuals, as well as society in the twentieth century. Objectively, it reflected the disappointment and boredom of the generation that lived the post-World War I experience. "The Waste Land" is the most convincing display of spiritual decline, psychological frustration, and disappointment immediately after World War I. The decade of the 1920s was a decade when the English people recovered from the shock of the First World War and hoped to regret it. The war had caused physical and psychological consequences, and the world has assumed an endless state of chaos. The world, portrayed by Eliot in the poem, was one in which faith in events was divine, and the universe was rationally organized andcompletely lost. Infertility and waste had replaced the traditional system and fertility. The poem was not merely a reflection of individual despair, but a point of view of total spiritual fatigue that transcended the modern world in all its forms. A contemporary sterile human society awaits its revival or renewal, of which may not even come. In fact, the infertility of the modern wasteland was emphasized through a combination of similarities and contrasts as Eliot relied on his extensive knowledge of European culture and different religions of the world. Eliot used several references throughout the poem to show the futility of life in London, which represented a chain of miserable memories associated with grief, loss, resistivity to life, and sleazy sex.

Eliot's poem dealt with the pain that came from the realization that there was truth beyond reality, but in human relationships, we can only ever get a brief look at it. The poem was isolated with 
men and women, and even among those that had relied on love in Eliot's world. There is only the pain that arises from the feeling that something painful is missing or, as is well known, resigned to the acceptance of human scarcity without much hope of change. "The Waste Land" paints Eliot's view on the permanent problem of human suffering, represented by pain and evil. This religious feeling makes him attribute human suffering to human sin. Both original sin and suffering are inextricably linked. In the poem, Eliot thinks of the original sin as sexual desire or lust, therefore, the passionate surrender of one's self to sex lies at the root of all human suffering.

In fact, the issue of the contradiction between love and lust in which Eliot revealed the corruption of sex that occurred in the modern society also clearly showed the subject of crisis. The prevailing position in the society must be lustful whatever the consequences. Eliot states, "His vanity requires no response and makes a welcome of indifference". He is not interested in exciting or satisfying her, rather, just obsessed with his own gratification. Love in the modern society is not really love; it is simply a thin saturation of physical desire. It is practical, boring, and meaningless. Love was once dear but now reduced to sex for pleasure and nothing else. Love in the past was permanent and true, while the love of the modern world is fleeting and awe. The transformation of the poem from the present to the past and vice versa emphasized the subject of crisis. Ancient legends, classic legends, suggested ancient literary masterpieces, and monuments in the history of the world are often combined side by side in the context of contemporary calamities and characters, casting new and glowing light, both in the past and present. Eliot is aware of the conflicts, contradictions, andtensions that were taking place in his community and was disappointed with the society he described as a wasteful land, but showed hope and ways of revival. He asserted: "If people become ready to give, sex will gain a new meaning as an expression of passion, and will not be dashed. If they support each other, they will be able to interact their true 
feelings and listen to others. Finally, if they put restraint, their faith will restore and they will not be afraid of life or death".

The poem "The Hollow Men", which is a poem about the problems of belief and sometimes, just considered an extension to "The Waste Land", also presented the theme of crisis (Cooper 2006: 55). The poem is loaded with bilateral oppositions that starkly depict men's hollow crisis of modern wasteland. The earth, in this poem, is the dead earth and the people living here are dead and living at the same time. At the beginning of the poem, the poet showed the variation between the deficiency of many ideas (hollow/stuffed) and undoubtedly wanted to express what men lack and what they have in large quantities. Men were hollow or stuffed in a pair of binary antibodies that the poet showed two different types of men (or we can say a double standard of the human mind) - one is naked of spirituality and the other is a straw man who knows nothing all. This contradiction in the human mind created a crisis in the society and gradually led to the anatomy of its chains. In the poem, the poet showed the opposition between several binary antibodies which both understand anticipation and fulfillment along with failures in the last lines. The people of this land have no real value or importance, and so, there are conflicts and crises everywhere. These conflicts and crises are responsible for corrupting humanity and damaging the means of communication between people. The result is fissure and fragment in the structures of the society.

In fact, we can conclude that Al-Bayati and Eliot presented the issue of crisis in their poetry by referring to the conflicts or contradictions between several binary antibodies. They regretted the fragmentation of the modern society which in the past had traditions, customs, and values that one could be proud of. The poets were dissatisfied because the modern world was not conducive to equality, unity, and solidarity - values that are necessary to promote a sense of well-being, tranquility, and harmony in the society. These poets asserted that what was once united and collected together exploded in shrapnel. The isolated arrogance of the person's self-faces the other aspects of survival 
Modernism in the Poetry of Abdul Wahab Al-Bayati and T. S. Eliot: a

Comparative Study

Dr. Thabit Shihab Ahmed Ahmed

مجلة وادي النيل للار اسات و البحوث الإنسانية والاجتماعية والتربوية (مجلة علمية محكمة)

across an empty place. The branches of knowledge, things, and words indicated that they dedicated each other and the world of men was one of the fragmented worlds and are parts of a broken world. The absence of ethical and moral values leads to permanent pain, anxiety, and chaos. It should be noted, however, that although both Al-Bayati and Eliot dealt with crisis, the implications of their treatment varied dramatically. The individual and special implications in dealing with the same subject resulting from such repercussions gave strength, connection, and special importance to their literary fulfillment.

\subsection{Symbolism}

Symbolists seek to suggest, conjure or merge what can actually be described through language through images. Symbols were used to suggest more than can be expressed in words. This was used to make an uncommon idea seem uncommon. The symbol was not only limited to poetry, but also extended to other art forms, especially painting. Icons made hair more musical by pressing the rhythm, adding the sweetness of the poetry and making it interesting. A symbol, in the broadest sense of the word, is anything that refers to something else; in this sense, all words are symbols. As is common in discussing literature, however, the symbol is applied only to a word or group of words that denotes an object or event that indicates as such, it refers to something else; this means that words refer to something that refers to a group of references that transcend themselves (Abrams, 2012: 175).Thus, through the use of spoiled language, symbolism attempted to provoke a picture of a certain idea using some external factors. Spiritual literature and the expansion of imagination. He was brought into the unknown light, dark and mysterious, and therefore, he was the happiest of readers and greatly adorned the language and style of literature. In France, the main defenders of the symbol were: Stéphane Mallarmé, Remy de Gourmont, Paul Verlaine, Jean Nicolas Arthur Rimbaud, Jules Laforgue, Edouard Dujardin, Charles Pierre Baudelaire, and Marcel Schwob. Later, 
Mallarmé became a sage and a saint of the symbolic movement. (Wimsatt Jr. \& Books, 1964: 502)

Abdul Wahab Al-Bayati is one of the poets of the modern Arabic poetic Renaissance, which appeared at the end of the first half of the twentieth century by young poets. Al-Bayati was one of them, and then became one of the most famous. Al-Bayati was unique as the richest among his colleagues of symbols in terms of abundance and significance and the capacity of employment.Abdel Wahab al-Bayati's poetry began to obtain ambiguous dimensions of love, using the symbols and inspirations taken from the great Arab mystics and the rich Arab history.

Al-Bayati reveals in his long poetic experience his awareness of the concept of the symbol and the need for it. He has a wide range of reading and comprehension, which enabled him to possess a material in which depth and self-reflection of events, personalities and objects correspond to a psychological-artistic need to invent new ways to express a new era. The new poetic style, which reconciles between these symbols, their historical affiliations and their positions, and the reasons of the new era in its crises, successive events, and the loss of man among all of them. The first stage in the formulation of symbols in the poetic life of Al-Bayati was knowledge of the crisis and the discovery of the appropriate symbols to express it to give useful and influential indication. That stage followed by the process of selection and scrutiny among a large number of aspects of heritage that can be symbols, and perhaps the choice is one of the most difficult stages. Not everything that belongs to the past is a myth, a historical, or a religion that can carry symbolic usefulness.Al-Bayati had a great deal of symbols in his long poetic career. The most prominent sources were mythology, religion, history and innovation. They do not stand apart from each other, but they sometimes meet or overlap with each other, so that the different symbols can be combined in one text.

Al-Bayati had a feeling of alienation that appeared early in his poetry life. Al-Bayati's feeling of alienation and isolation was not arbitrary, but a feeling stemming from a vivid experience in which 
Modernism in the Poetry of Abdul Wahab Al-Bayati and T. S. Eliot: a

Comparative Study

Dr. Thabit Shihab Ahmed Ahmed

مجلة وادي النيل للار اسات و البحوث الإنسانية والاجتماعية والتربوية (مجلة علمية محكمة)

the poet lived. Al-Bayati suffered early exile, working in a remote part in Iraq far from his family and the places where his childhood memories were associated. This has the profound effect in himself that loves freedom.According to Muhsin Jassim Al-Musawi, who discusses the issue of exile in modern Arabic poetry. Al- Musawi confirms that more than any modern Arab poet, addressing the late Iraqi poet Abdul Wahab al-Bayati issue of exile. However, alBayati's poems dealing with exile suggest that legendary space, freedom and abundance cannot preserve the poetic sound for a long time. By impersonating similar poets, such as Nazim Hikmat, Rafael Alberti, and Federico Garcia Lorca, al-Bayati reconstructs a new homeland, a poetic space of ancestors and grandparents who share many commonalities and who give him descent and sonship. No wonder then that the poem grows to a homeland where the poet remain alive after passing disasters and hard times(Al-Musawi, 2001: 212). His poem "Elegy to the Unborn City" clearly illustrates these themes:

"In it he taught me to wait for the night and the day

And to search for a hidden, enchanted city.

On the map of the world

Similar to my city

In the color of its eyes and in its sad laugh,

But not wearing

The tatters of the wandering clown,

Nor does its summer buzz with people and flies."(Al-

Bayati, 2004: 43)

Al-Bayati went on to expand the use of the symbol, when he discovered the technique of the mask, by employing characters, or events, derived from myth, religion, history, literature and reality, and its main sources, to increase the number of symbols.Al-Bayati took advantage of symbols of other civilizations, before he tended to use Arabic symbols, in that they are mythological figures, without getting into the context of the legend itself. Then he developed to take advantage of the personal life of the whole, and 
this applies to foreign symbols, as the Arab symbols.Death, despair, and weariness prevail over the poems of al-Bayati, who were biased in an earlier stage. They almost all show that the existential tendency in his poetry and despite what may sometimes inform him of despair reaches the limit of death, remains a trend not inherent in the same poet, and composition. It is imposed on him by what has surrounded his life, and the life of the community in which he lives. This feeling is not alienation existential or a loss such as that shown by some European writers, and this evidence that al-Bayati, quickly left this stage when some of the causes of objectivity, and found other factors placed in the heart of social life, political and intellectual.

The cultural reality represents an area in which al-Bayati's personality moves more than other fields. Al-Bayati was therefore more capable of diagnosing and sorting out the diseases of this reality, because of the severity of his suffering and the negative effects imposed upon him. Al-Bayati produced symbols that reflect the cultural reality, (Frogs), which is a picture of a group of people whose desires and purposes are full of necessities that call for the justice of life. They are like men and not men in the belief of alBayati.He used the symbol of 'frogs' in his poem 'Something about Happiness':

"Ah, crying is in vain

I am ashamed, Muhammed,

The frogs

Stole happiness from us,

Yet in spite of the suffering, I am

On the road to the sun, marching."(Al-Bayati, 2004: 29)

The existence of this model is not limited to a specific time, but it can appear at any time and place, and in political positions, despite its differences. The features of these symbols were manifested in a more sophisticated model, the 'clown' that is repeated in Al-Bayati's poetry in more detail, especially in his poem "Elegy to Clown". 'Yellow newspapers' was one of the symbols that Al-Bayati used to mean the monitoring of some 
Modernism in the Poetry of Abdul Wahab Al-Bayati and T. S. Eliot: a

Comparative Study

Dr. Thabit Shihab Ahmed Ahmed

مجلة وادي النيل للاراسات و البحوث الإنسانية والاجتماعية والتربوية (مجلة علمية محكمة)

negative aspects in public life, and cultural in particular, as in a poem by the same title.

One cannot ignore the important and prominent aspect of the poetic personality of the contemporary Iraqi poet Abdul Wahab alBayati, namely, the use of masks and mystical and historical symbols in the political field. We mean the expression of the poet's rejection and protest against the repressive political regimes repressive freedoms in the language of history and the symbols and masks of rejection of injustice and calling the society to freedom.Al-Bayati used symbols to match the political life that Iraq was going through and these symbols: the 'hypocrite', which symbolizes the volatile politician in his political positions.AlBayati uses another symbol, 'The Fox' because of its deceit, deception and evasion, which are the main qualities of hypocrisy and hypocrites. Therefore, al-Bayati promotes the symbol of his hypocrisy, in addition to the image of the professional politician.The 'crow' is a symbol of pessimism and a harbinger of separation. Al-Bayati has also made him a symbol of hypocrisy, which refers to the letters that dominate the pages of the hypocritical newspapers, as in the poem "The Crow".

Al-Bayati had a strong sense of loneliness, and was confused, early, by tampering with the futility, to be part of a general feeling imposed by the circumstances surrounding him. Al Bayati employs the symbol to express unity in a poem (A Song to my People). The symbol in the poem is 'the cross', including a sign of sacrifice, and the poem highlights the image of the sacrificer and the only one defending his people. His image is mixed with the image of Jesus Christ.

According to Shawkat M. Toorawa, al-Bayati, used masks or personas in his poetry to reflect his need to find a way to demonstrate his strong resistance to the social and political conditions in the Arab world caused by the Arab regimes. This resistance led him to prison and exile to write after that the wonderful poems that reflect the life of exile and filled with the 
masks and symbols that gave it strength and durability (Toorawa, 2015: 104).

The mask in Arabic poetry has many factors, including political, national, cultural, artistic and social factors. In addition, the mask has several types, including religious, mystical, historical, literary, mythical, and popular, and its patterns are simple, complex and inventive. All kinds of masks are mainly related to the ability of the poetic poet who employs them to describe the circumstances surrounding him.Abdul Wahab al-Bayati employed events and historical and religious figures to be an expression of the positions he wants, or to judge the age and shortcomings of it through which he chooses the events and personalities that fit the content of his experience. Thecontact with them is not connected to him and his historical and religious inspiration is a picture of the reality provoked by the concerns of political issues, where the poet envisions the color and lines of his opinion.

Al-Bayati occupies the first rank among poets in deriving the mask from the Sufi heritage. Not only does the whole frame of the personality remain, but also the mask is re-produced by other texts, which leads to the renovation of the signs. Al-Bayati relied on the mask in many poems.He relied on myths and access to the Arab heritage, and the world. The symbol of "Aisha" is his most comprehensive and problematic symbolism in his poetic speech, a symbol of openness, rebellion and continuous development through his successive writings. In this symbol, he recreates the myths and experiences of love.Al-Bayati used figures from the past Arab history and world culture as a personality in his poetry, who talk about their experience in terms of their association with modern times. Using someone as a mask reduces Al Bayati's direct involvement with current negative conditions in the Arab world. In addition, allowing him to objectively criticize the evils of this reality and offer his aspirations for a better life without being an educational or ideological cause.

T.S.Eliot also became part of the symbolic movement in England, after Ezra Pound introduced him to the greats of his time. $\mathrm{He}$ is greatly influenced by the symbols he derives most from - 
thoughts, characters, attitudes, moods, phrases and even titles of his works. Eliot tries to express the mood of his characters through 'objective correlative', a term that has become a mark of Eliot. Using 'objective correlative', he tries to shed light on what lies in the psychology of the characters and feels that some external factors should be used to express the inner self of the characters on the stage (Joshi, 2016: 50).Eliot is one of the most effective poets of modern times. He became the name of the paragon in the modern world of poetry for his remarkable use of symbols in his poems. Like some great poets, Eliot was greatly influenced by French symbols, exceptionally by Laforgue, Mallarme, and Gautier. Eliot cheered Donne for the reason that he attracted him to French symbols. Eliot believed that symbols enable him to express ambiguity, complexity, and modernity. He thought that to satisfy the thirst for spiritual realization, he must portray and interpret abstract and mystical ideas through symbols.

Eliot adopted some traditional symbols and images in his poetry, thus, he picks out the cross of Christianity; deserts, dust, and wasteland for infertility in spiritual expressions, and water, particularly rain or floods to revive spiritual or awakening of the broken souls. The rose represented love, while fog, evening, and night symbolized the lost soul moving around in the afterglow world.

In "Four Quartets", a special image and symbol were of particular importance. This group focused on gardens and includes linked specifics such as flowers, fountains, birds, and children. The symbolic theme is obvious in the title of the poem "The Waste Land". The wasteland of the poem is the symbol of a gloomy and sterile country ruled by an impotent king. Puritan soon identified this widespread infertility as infertility according to their mood. Eliot's poems are full of many distinctive symbols. Undoubtedly, some of these symbols are usually Indian in origin and application, such as the lotus, wheel, dark, light or sunlight, purity by fire, river, sea, and bird. 
مجلة وادي النيل للاراسات والبحوث الإنسانية و الاجتماعية والتربوية (مجلة علمية محكمة)

(ISSN : 2536 - 9555)

The mask is often associated with the idea of ability. Primeval people sought through it to get out the evil spirits. Greek genius was used to evoke universal types. Even modern psychological theories of the defense mechanism suggest that men are still intrigued by the symbolism of the mask. We should not be surprised, then, if some dramas of our time show renewed interest in this ancient pillar as a device to shed light on the human situation (Shaughnessy, 1984: 205).

Abdul Wahab al-Bayati and T.S. Eliot agree on the subject of symbols and their purpose. If al-Bayati is a diligent student in the use of symbols, Yeats is considered his teacher in his adoption of the symbolism. Both use symbols in many of his poems. In addition to repeating symbols in different locations and in different contexts for different purposes. Both use symbols such as repetitive characters as well as some living and non - living objects. They dealt with the political, social and cultural conditions of their countries. Al-Bayati, when became old and his grip no longer controlled the workmanship, reduced the use of the symbol and the adoption of the statement, but his artistic ability, which reached maturity, exceeded his earlier period. While Eliot continued to use symbols until the last poem he wrote. In order to remain the flagship of the symbolic movement and its real representative in the English literature.

\subsection{Mythology}

In fact, one of the most striking artistic phenomena of the contemporary poetic poem is its clear reliance on the evocation and use of different mythological texts and symbols. It is indisputable that myths have become an important artistic structure of contemporary poetic text.The contemporary poet turned to the use of myths through the adoption of symbolic and artistic dimensions through which to express the issues of real life. In addition to the inspiration of myths enriches the work of art, especially if it includes a contemporary position and expressed a new experience. The Modern Western poet that having learned the patterns of his poems that he found saturated with the world of ancient legends 
Modernism in the Poetry of Abdul Wahab Al-Bayati and T. S. Eliot: a

Comparative Study

Dr. Thabit Shihab Ahmed Ahmed

مجلة وادي النيل للاراسات و البحوث الإنسانية والاجتماعية والتربوية (مجلة علمية محكمة)

influenced the contemporary Arab poet. The Arab poet also tried to use all myths in the formulation of his poetic text according to his vision of the positions he tried to deal with.

Contemporary poets used the "myth" internally, structurally, by inspiration and transformed into poetry. The contemporary poet employs myths to express a contemporary experience by taking it out of its old domain and bringing it into contemporary dimensions. It expresses the experience of the poet who embodies the character or the event to express through them or through one of them an indirect expression of his sense. Thus, myth comes out as a history and becomes a series of dramatic transformations.Myth has contributed greatly to the formation and construction of poetic poems by contemporary poets. Abdul Wahab al-Bayati as one of these poets has shown his poetic texts this great rush towards the myth. The legend enriched and influenced his poetry texts in different terms and symbols. In addition to that, through the legend, the poet was able to express many of the ideas that filled him and through it all about what is going on within the feelings and concerns of the issues brought up and dealt with in his poems. Myth was the main theme of his poetic themes.

According to Helene Morales, modern Arab poets, especially the leading poets Nazik al-Mala'ika, Abdul Wahab al-Bayati, and Bader Shakir al-Sayyab, who were influential in the 1950s and beyond, consciously used especially Greek legends and the classical legends about the past. Morales confirms that the title of the poem of Al Bayati "Greetings, Athens" declares with resentment his discussion with the past and this poem is inspired by the Western myth to solve the problems of the Arab community. In the poem, the Greek gods were severe and brutal and the world needed a poet, Ulysses, to free the world from chains of injustice(Morales, 2007: 17).

In fact, there are several motives behind the adoption of AlBayati of the myth. One of them is self through the myths of exile and away from the family and love that were a reflection of his life that he lived. In addition to the legends of death and the 
resurrection of his difficult life. The artistic motives have also contributed to enriching the legend in the works of Al Bayati.Al Bayati found in the legend a haven for him. He believed that myth carried his worries and dreams, and enriches his intellectual world. The bitter reality pushed our poet to search for the cities of love, and to use the legendary cities and heroes to get rid of the falsities of our contemporary cities, and to download their thoughts and feelings, or to be among several means, through which it affects us.In addition, the artistic motives have a role in making al-Bayati use many legends. The poet of mythology attaches great importance to poetry. Al-Bayati believes that the symbol, legend and mask are the most important parts of the modern poem, without which the poem is hungry and without clothing and turns into a project or structure of a dead body.The suffering of al-Bayati is part of the suffering of human beings wherever they are and some of their torment. Therefore, we see him putting his hand in their hands to confront the oppressors of this world, and joining his voice to the voices of the free everywhere in order to combat this tyranny.

Eliot had a deep realization of the use of myth as a starting point for preserving a cultural or historical view. In his poem, "The Waste Land", myth was not just a false tactical metaphor but also an attempt to connect his own ideas and metaphorical uses to the cosmos in order to establish some external order of the chaos that he presents. Eliot linked many mythological threads to shape a complex traditional environment to explain nature and measure the deepness of the spiritual waste of the land that is a contemporaneous date. Many critics see Eliot as an outstanding writer in the mythology industry. They see him alongside his contemporaries such as Yeats, Thomas Mann, Joyce or Lawrence. The myth of Eliot is opposed to the mythology of other modernists. While for them it is a means of confirming values in the aware absence of the metaphysical foundations, for Eliot, it is a rather a placeholder for religious belief, the sign of a widespread, if not universal religious need. this literary world of poems and plays that 
Modernism in the Poetry of Abdul Wahab Al-Bayati and T. S. Eliot: a

Comparative Study

Dr. Thabit Shihab Ahmed Ahmed

مجلة وادي النيل للاراسات والبحوث الإنسانية والاجتماعية والتربوية (مجلة علمية محكمة)

build original legends while strengthening its national sense of nationalism.

In his poem The Waste Land, Eliot worries from the AngloAmerican culture in the twentieth century to reveal the distance of modern western countries from the natural world, close to anxiety. Whatever the complex desire to re-cooperate with natural powers. The fact that the dry poem of broken and scattered images reflects the divided state of the civilized soul and its unburned state. Eliot realized the feeling of spiritual distress of the modern era in which man fought and the descent of the human mind from the natural world. The study of images known in the poem illustrates Eliot's recent sense of anxiety, which foreshadows much critical environmental debate about the mythical symbols in the poem (Hasan, 2019: 30).

\section{Conclusion}

The Iraqi poet Abdul Wahab Al-Bayati is one of the most famous poets and writers who carried the obsession of modern Arabic poetry in Iraq and the Arab region. He is the mastermind of many legends and the creator of the mask in contemporary Arabic poetry and his poems are full of symbols. The main sources of AlBayati's work were varied, literary, historical, religious, traditional, popular and mythological. Therefore, he evoked many different models and personalities in terms of sex and race. In his poems, Al-Bayati addressed the issues of revolution, oppression, extortion, exile, alienation, rebellion, pain, suffering and death.Al-Bayati used many symbols in his long poetic life. The most prominent sources were legends, religion and history, in addition to his own creation of a number of important symbols in his poems. They do not stand apart from each other, but they sometimes meet or overlap with each other, so that different symbols can be combined into one text.

Al-Bayati is the Iraqi-Arab poet who distinguished himself from other poets in his brilliant use of the mask. He has been using the masks and symbols in his poetry to reflect his need to find a 
way to prove his strong resistance to the social and political conditions in the Arab world caused by the Arab regimes. This resistance led him to prison and exile to write then the wonderful poems that reflect the life of exile and full of masks and symbols that gave his poems strength and durability.

Al-Bayati found in the legend a haven for him. He believed that the myth carries his fears and dreams; in addition to that, it strengthens his intellectual world. The bitter reality pushed AlBayati, the poet and man, to search for cities of love, to use cities and mythical heroes to get rid of the falsity of our modern cities, to download their ideas and feelings, or to be among several means through which the poet could influence us.

The great poet T.S. Eliot was one of many famous writers and poets who believe in East-West communion and believe in modernity, in addition to their belief in magic, mystery and legends. Eliot believes that East-West relations are one of the most vital links. For Eliot, the Arab world was an inseparable part of the East, unlike many writers and critics of his time who believe that the East means India or China only and that both Persian and Arabic cultures in the Near East or Middle are not from the East.

All literary critics agree that the great poet T.S. Eliot is the true representative of the symbolic movement in English literature through the ages. Many poets from East and West have followed the same Eliot's way in his wonderful use of symbols, masks and legends. Al Bayati is one of these poets. The method of using the symbols is similar between the two poets as well as the use of myths. Al-Bayati had taught a lot of information about Yeats and his life through many books in his study in Baghdad and he was greatly affected by him. So imaginatively, we can say that T.S. Eliot is a professor of Abdul Wahab Al-Bayati.

Abdul Wahab Al-Bayati and T.S. Eliot agree on the subject of symbols and their purpose. If Al-Bayati is diligent in using symbols, T.S. Eliot is seen as a guide in his adoption of the symbolism. Both use symbols in many of his poems. In addition to repeating symbols in different locations and in different contexts for different purposes. Both use symbols such as repetitive 
Modernism in the Poetry of Abdul Wahab Al-Bayati and T. S. Eliot: a

Comparative Study

Dr. Thabit Shihab Ahmed Ahmed

مجلة وادي النيل للار اسات و البحوث الإنسانية والاجتماعية والتربوية (مجلة علمية محكمة)

characters as well as some living and non-living objects. They dealt with the political, social and cultural conditions of their countries as well as the circumstances of the entire world.

\section{References}

Abrams, M.H. 2012. A Glossary of Literary Terms. New York Gurgaon, India: Macmillan Publishers India Ltd.

Al-Bayati, A. 2004. Abdul Wahab Al-Bayati: Love, Death and Exile, trans. Bassam K. Frangieh. Georgetown University Press.

Al-Musawi, M. J. 2001. 'Abd Al-Wahhab Al-Bayātī's Poetics of Exile. Journal of Arabic Literature, Vol. 32, Iss. 2, pp. 212238.

Boullata, I. 2001. The Masks of 'Abd al-Wahhāb al-Bayātī. Journal of Arabic Literature, Vol. 32, No. 2, pp. 107-118.

Cooper, John Xiros. 2006. The Cambridge Introduction to T.S. Eliot. Cambridge: Cambridge University Press.

Eliot, T. S., Ricks, C., \& McCue, J. 2015. The Poems of T. S. Eliot: Collected and Uncollected Poems (Volume 1). Harlow, Essex: Faber \& Faber.

Hasan, M. 2019. The explication of mythology and ecology in Eliot's The Waste Land. Studies in Literature and Language, 19(1), 30-36.

Joshi, R. C. 2016. Symbolism and TS Eliot's Theory of Objective Correlative. International Research Journal of Interdisciplinary \& Multidisciplinary Studies, 2, pp. 48-55.

Khoury, D. R. 2010. The Great War in the Memoirs and Poetry of the Iraqis Liebau, in Heike Liebau (ed.). The World in World Wars: Experiences, Perceptions and Perspectives from Africa and Asia: Brill, pp. 313-340. 
مجلة وادي النيل للاراسات و البحوث الإنسانية والاجتماعية والتريوية (مجلة علمية محكمة)

(ISSN : 2536 - 9555)

Morales, H. 2007. Classical mythology: a very short introduction (Vol. 167). Oxford University Press.

Moreh, S. 1976. Modern Arabic Poetry: 1800-1970; the Development of Its Forms and Themes Under the the Influence of Western Literature, Vol. 5, 216-266. Brill Archive.

Shaughnessy, E. L. 1984. Masks in the Dramaturgy of Yeats and O'Neill. Irish University Review, Vol. 14, No. 2, pp. 205220.

Thompson, T. L. 2017. Speaking Laterally: Transnational Poetics and the Rise of Modern Arabic and Persian Poetry in Iraq and Iran (Doctoral dissertation, University of California, Los Angeles).

Toorawa, S. M. 2015. Poetry, in Dwight F. Reynolds (ed.). The Cambridge Companion to Modern Arab Culture. Cambridge University Press, pp. 96-111.

Williamson, George. 1998. A Reader's Guide to T.S. Eliot: A Poem-by-Poem Analysis. Syracuse: Syracuse University Press.

Wimsatt, W.K. Jr. \& Books, C.1964. Literary Criticism: A Short History. Oxford \& IBH Publishing Co. 